\title{
Mesenchymal stem cell therapy in pulmonary fibrosis: a meta-analysis of preclinical studies
}

\author{
Deng-Yuan $\mathrm{Li}^{1,2,3}$, Ru-Fang Li ${ }^{2,3}$, Dan-Xiong Sun ${ }^{2,3}$, Dan-Dan $\mathrm{Pu}^{2,3}$ and Yun-Hui Zhang ${ }^{1,2,3^{*}}$ (D)
}

\begin{abstract}
Background: Pulmonary fibrosis (PF) is a devastating disease characterized by remodeling of lung architecture and abnormal deposition of fibroblasts in parenchymal tissue and ultimately results in respiratory failure and death. Preclinical studies suggest that mesenchymal stem cell (MSC) administration may be a safe and promising option in treating PF. The objective of our meta-analysis is to assess the efficacy of MSC therapy in preclinical models of PF.

Methods: We performed a comprehensive literature search in PubMed, EMBASE, Web of Science, and Cochrane Library databases from inception to March 17, 2021. Studies that assessed the efficacy of MSC therapy to animals with PF were included. The SYRCLE bias risk tool was employed to evaluate the bias of included studies. The primary outcomes included survival rate and pulmonary fibrosis scores. Meta-analysis was conducted via Cochrane Collaboration Review Manager (version 5.4) and Stata 14.0 statistical software.
\end{abstract}

Results: A total of 1120 articles were reviewed, of which 24 articles met inclusion criteria. Of these, 12 studies evaluated the survival rate and 20 studies evaluated pulmonary fibrosis scores. Compared to the control group, MSC therapy was associated with an improvement in survival rate (odds ratios (OR) 3.10, 95\% confidence interval (Cl) 2.06 to $4.67, P<0.001, P^{2}=0 \%$ ) and a significant reduction in pulmonary fibrosis scores (weighted mean difference (WMD) $2.05,95 \% \mathrm{Cl}-2.58$ to $-1.51, P<0.001, P^{2}=90 \%$ ).

Conclusions: MSC therapy is a safe and effective method that can significantly improve the survival and pulmonary fibrosis of PF animals. These results provide an important basis for future translational clinical studies.

Keywords: Pulmonary fibrosis, Mesenchymal stem cell, Preclinical studies, Therapy, Meta-analysis

\section{Background}

Pulmonary fibrosis (PF) is a chronic, life-threatening disease with a gradual worsening of pulmonary function and shortness of breath, and the median survival time of patients with idiopathic pulmonary fibrosis (IPF) was estimated to be $2.5-3.5$ years $[1,2]$. PF is characterized by alveolar epithelial cell injury, remodeling of lung

\footnotetext{
* Correspondence: yunhuizhang3188@126.com

${ }^{1}$ Faculty of Life Science and Technology, Kunming University of Science and Technology, Kunming 650500, People's Republic of China

${ }^{2}$ The Affiliated Hospital of Kunming University of Science and Technology, Kunming 650500, People's Republic of China

Full list of author information is available at the end of the article
}

architecture, abnormal accumulation of extracellular matrix, and fibroblasts in parenchymal tissue [3, 4], which ultimately results in respiratory failure and death [5]. The prognosis of IPF is poor, with a mortality rate comparable to advanced tumors [6]. In recent years, the treatments of medicine such as pirfenidone and nintedanib have improved lung function for patients with IPF [7], but neither one has a certain advantage on mortality outcomes, often necessitating lung transplantation $[8,9]$. Therefore, it is important to detect innovative options and new therapeutic strategies for the management of pulmonary fibrosis. 
In recent years, mesenchymal stem cells (MSCs) have received increasing attention in the field of regenerative applications, because of multi-lineage differentiation potential, migratory ability, and self-renewal properties [10, 11]. MSCs are derived from a variety of organs and tissues, such as the bone marrow and adipose tissues, and can home to the sites of injury. The therapeutic values of MSCs have been demonstrated in various diseases, including ischemic heart failure, pulmonary arterial hypertension, stroke, chronic kidney disease, and sepsis [1215]. Accumulating evidence suggests the role of MSC administration in attenuating the disease by antiapoptotic, immunomodulation, and anti-inflammatory effects [16-18]. However, the underlying molecular mechanisms are much more complicated and have not yet been fully recognized.

Several studies suggested that MSCs have the capacity to suppress inflammation, reduce fibrosis, and prolong the survival time for preclinical models of $\mathrm{PF}$, which was induced by bleomycin, silica, paraquat (PQ), and radiation [10, 19-24]. However, the design projects, including MSC dose, type, route, source, and time interval, in each research are so different that the final therapeutic effect is difficult to evaluate. As a result, the best way of MSC therapy remains unclear. Therefore, we collected data from all relevant studies and conducted a metaanalysis to assess the efficacy of MSC treatment.

\section{Methods}

\section{Data source and search strategies}

This meta-analysis followed the Preferred Reporting Items for Systematic Reviews and Meta-Analyses (PRISMA) guidelines (Additional file 1: Table S1) [25]. A systematic literature search was performed using PubMed, EMBASE, Web of Science, and Cochrane Library from inception to March 17, 2021. We also manually reviewed the reference cited with the articles. The detailed search strategy is described in Additional file 2: Table S2. The language was limited to English.

\section{Eligible criteria}

The following inclusion criteria were set: (1) the study involved animal models of pulmonary fibrosis (all species and sexes); (2) all pulmonary fibrosis animal models were subjected to MSC treatment; (3) studies that include efficacy outcomes, such as survival rate and pulmonary fibrosis scores; and (4) studies have a control group.

Studies were excluded from the meta-analysis for the following reasons: (1) all inclusion criteria were not fulfilled; (2) the MSCs used in the study were differentiated, or engineered to alter the expression of specific genes; (3) meeting abstracts, case reports, and case series; (4) review or meta-analysis; (5) the study was duplicated; and (6) studies published in a non-English language.

\section{Study selection and data extraction}

Two investigators (Deng-Yuan Li and Ru-Fang Li) independently screened the literature according to the search strategy. Any disagreements were reviewed and resolved by a third investigator (Dan-Dan $\mathrm{Pu}$ and Dan-Xiong Sun). After identifying the articles that met the inclusion criteria and exclusion criteria, we extracted the data using a standardized collection form that included the first author, year of publication, animal characteristics (species, gender, and model), intervention details (origin, dose, route, and timing of MSC transplantation), and follow-up (observation time of outcomes after MSC therapy) and then measured the correlation with our primary outcomes (survival rate and pulmonary fibrosis scores). In the case of missing or unclear data for the primary outcome measures, an attempt was made to contact the author for clarification.

\section{Assessment of risk of bias}

Risk of bias was assessed according to the Systematic Review Centre for Laboratory animal Experimentation (SYRCLE) bias risk tool [26]. The components included random sequence generation, performance bias, detection bias, attrition bias, reporting bias, and other sources of bias. For each item, studies were categorized as high, low, and unclear risk of bias.

\section{Primary outcomes}

The main study outcomes of this meta-analysis were survival rate and pulmonary fibrosis scores [27].

\section{Statistical analysis}

Statistical analysis was performed via Stata 14.0 statistical software and Cochrane Collaboration Review Manager (version 5.4). Continuous and dichotomous outcome variables were respectively described as weighted mean difference (WMD) and odds ratios (ORs) with 95\% confidence intervals (CIs). The chi-squared test and $I^{2}$ parameter were used to measure heterogeneity [28]. The fixed effects model was used for metaanalysis when $P>0.1$ and $I^{2}<50 \%$, and the random effects model was used when $P<0.1$ and $I^{2}>50 \%$. If heterogeneity was significant, subgroup analysis and metaregression were performed to further exploration. We assessed the potential for publication bias using Funnel plots and Egger's regression test [29]. Differences for which $P<0.05$ (two-sided) were considered statistically significant. 


\section{Results}

\section{Study selection}

According to the search strategy, we identified 1654 studies related to mesenchymal stem cell therapies for pulmonary fibrosis, and 534 duplicate articles were removed using Endnote X 9 software. By reading the titles and abstracts, 122 articles were isolated for full-text review. Finally, 24 articles involving 564 animals were included in this meta-analysis after study selection (Fig. 1) (If more than one intervention was provided in a single study, each intervention was regarded as independent.).

\section{Study characteristics}

The basic characteristics of 24 articles are listed in Table 1. The articles were published between 2005 and 2020. The majority of studies were conducted in rodents (rats and mice). One study was carried out in tree shrews. The pulmonary fibrosis animal model in most studies was induced by bleomycin, radiation, or paraquat. Stem cell types included bone marrow mesenchymal stem cells (BMSC) $(n=15)$, adipose-derived mesenchymal stem cells (ADMSC) $(n=6)$, umbilical cord mesenchymal stem cells (UCMSC) $(n=3)$, amniotic membrane mesenchymal stem cells (AMSC) $(n=2)$, human embryonic mesenchymal stem cells (EMSC) $(n=1)$, and human menstrual blood-derived mesenchymal stem cells (MenSC) $(n=1)$. The doses of interventions ranged from $10^{3}$ to $10^{7}$ MSCs, which were injected intravenously in 25 animal studies, via intraperitoneal transplantation in two studies, and intratracheal injection in one study. Timing of cell administration ranged from $1 \mathrm{~h}$ to 60 days after induction of the PF model. However, the majority of reports treated animals with stem cells prior to injury or evidence of PF. The duration of follow-up ranged from 1 to 60 days. Otherwise, three of the articles included multiple studies. Therefore, the meta-analysis included a total of 28 animal studies involving 564 animals.

\section{Risk of bias (SYRCLE tool)}

Each risk of bias item of all articles is shown in Fig. 2. No study fulfilled all ten criteria for low risk of bias. Most studies demonstrated similar baseline characteristics about experimental and control groups. Among the 24 articles, none of the studies accurately described the random sequence generation. Therefore, the risk of bias

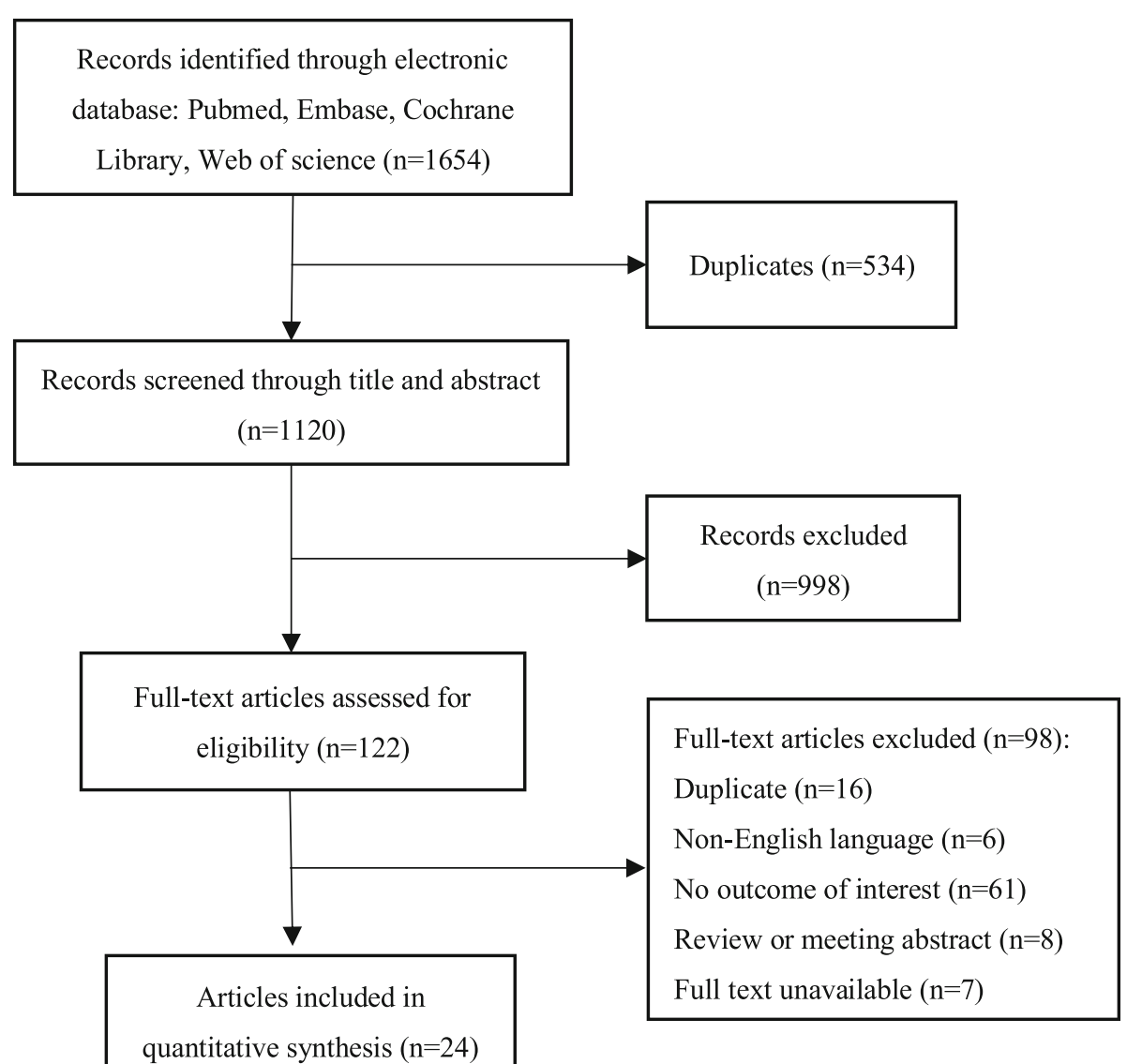

Fig. 1 Flow diagram of the study selection 
Table 1 General characteristics of preclinical studies investigating the efficacy of MSC therapy in models of PF

\begin{tabular}{|c|c|c|c|c|c|c|c|c|c|c|c|}
\hline Author (year) & Country & $\begin{array}{l}\text { Species, } \\
\text { strain, } \\
\text { gender }\end{array}$ & $\begin{array}{l}\text { No. of treated } \\
\text { animals }\end{array}$ & $\begin{array}{l}\text { No. of } \\
\text { controls }\end{array}$ & $\begin{array}{l}\mathrm{PF} \\
\text { model }\end{array}$ & $\begin{array}{l}\text { MSC } \\
\text { source }\end{array}$ & $\begin{array}{l}\text { MSC } \\
\text { dose }\end{array}$ & $\begin{array}{l}\text { MSC } \\
\text { route }\end{array}$ & $\begin{array}{l}\text { Transplant } \\
\text { type }\end{array}$ & $\begin{array}{l}\text { Time of MSC } \\
\text { therapy after } \\
\text { PF }\end{array}$ & $\begin{array}{l}\text { Follow- } \\
\text { up } \\
\text { (days) }\end{array}$ \\
\hline $\begin{array}{l}\text { Li et al. (2017) } \\
\text { [43] }\end{array}$ & China & $\begin{array}{l}\text { Mouse } \\
\text { C57BL/6, M }\end{array}$ & 5 & 5 & Radiation & BMSC & $2.0 \times 10^{6}$ & iv & Allograft & $2 \mathrm{~h}$ & $42 d$ \\
\hline $\begin{array}{l}\text { Xia et al. A } \\
\text { (2015) [44] }\end{array}$ & China & $\begin{array}{l}\text { Mouse, NR, } \\
\text { NR }\end{array}$ & 25 & 25 & Radiation & BMSC & $1.0 \times 10^{3}$ & iv & Xenograft & $1 \mathrm{~d}$ & $28 d$ \\
\hline $\begin{array}{l}\text { Xia et al. B } \\
\text { (2015) }\end{array}$ & China & $\begin{array}{l}\text { Mouse, NR, } \\
\text { NR }\end{array}$ & 25 & 25 & Radiation & BMSC & $5.0 \times 10^{3}$ & iv & Xenograft & $1 \mathrm{~d}$ & $28 d$ \\
\hline $\begin{array}{l}\text { Xia et al. C } \\
\text { (2015) }\end{array}$ & China & $\begin{array}{l}\text { Mouse, NR, } \\
\text { NR }\end{array}$ & 25 & 25 & Radiation & BMSC & $1.0 \times 10^{4}$ & iv & Xenograft & $1 \mathrm{~d}$ & $28 \mathrm{~d}$ \\
\hline $\begin{array}{l}\text { Guo et al. } \\
\text { (2018) [23] }\end{array}$ & China & $\begin{array}{l}\text { Tree shrews, } \\
\text { NR, F }\end{array}$ & 20 & 20 & Radiation & UCMSC & $3.0 \times 10^{7}$ & iv & Allograft & $\begin{array}{l}1 \mathrm{~h}, 7 \mathrm{~d}, 14 \mathrm{~d} \\
21 \mathrm{~d}\end{array}$ & $28 \mathrm{~d}$ \\
\hline $\begin{array}{l}\text { F. Cahill et al. A } \\
\text { (2016) [45] }\end{array}$ & Ireland & $\begin{array}{l}\text { Mouse } \\
\text { C57BL/6, F }\end{array}$ & 5 & 5 & BLM & BMSC & $5.0 \times 10^{4}$ & iv & Allograft & $6-8 \mathrm{~h}$ & $28 d$ \\
\hline $\begin{array}{l}\text { F. Cahill et al. B } \\
(2016)\end{array}$ & Ireland & $\begin{array}{l}\text { Mouse } \\
\text { C57BL/6, F }\end{array}$ & 5 & 5 & BLM & BMSC & $5.0 \times 10^{4}$ & iv & Allograft & $9 d$ & $28 d$ \\
\hline $\begin{array}{l}\text { Zhang et al. } \\
\text { (2018) [24] }\end{array}$ & China & Rat, SD, M & 6 & 6 & Silica & BMSC & $2.0 \times 10^{6}$ & iv & Allograft & $28 d$ & $28 d$ \\
\hline $\begin{array}{l}\text { He et al. } \\
\text { (2020) [19] }\end{array}$ & China & Rat, SD, M/F & 22 & 20 & $P Q$ & AMSC & $2.0 \times 10^{6}$ & iv & Xenograft & $6 \mathrm{~h}$ & $21 \mathrm{~d}$ \\
\hline $\begin{array}{l}\text { Moroncini et al. } \\
\text { (2018) [46] }\end{array}$ & Italy & $\begin{array}{l}\text { Mouse } \\
\text { C57BL/6, F }\end{array}$ & 8 & 8 & BLM & UCMSC & $2.5 \times 10^{5}$ & iv & Xenograft & $1 \mathrm{~d}, 7 \mathrm{~d}$ & $21 d$ \\
\hline $\begin{array}{l}\text { Chen et al. } \\
\text { (2019) [10] }\end{array}$ & China & $\begin{array}{l}\text { Mouse } \\
\text { C57BL/6, M }\end{array}$ & 10 & 10 & $P Q$ & BMSC & $2.0 \times 10^{6}$ & iv & Allograft & $7 d$ & $14 d$ \\
\hline $\begin{array}{l}\text { Tashiro et al. } \\
\text { (2015) [47] }\end{array}$ & USA & $\begin{array}{l}\text { Mouse } \\
\text { C57BL/6, M }\end{array}$ & 5 & 12 & BLM & ADMSC & $5.0 \times 10^{5}$ & iv & Allograft & $1 \mathrm{~d}$ & $21 d$ \\
\hline $\begin{array}{l}\text { Ai et al. } \\
\text { (2019) [48] }\end{array}$ & China & $\begin{array}{l}\text { Mouse } \\
\text { C57BL/6, M }\end{array}$ & 10 & 10 & BLM & ADMSC & $5.0 \times 10^{6}$ & iv & Allograft & $1 \mathrm{~d}$ & $14 \mathrm{~d}$ \\
\hline $\begin{array}{l}\text { Zhang et al. } \\
\text { (2019) [20] }\end{array}$ & China & Rat, SD, M & 10 & 10 & $P Q$ & BMSC & $3.0 \times 10^{6}$ & ip & Allograft & $1 \mathrm{~h}$ & $1 \mathrm{~d}$ \\
\hline $\begin{array}{l}\text { M. Kumamoto } \\
\text { et al. (2009) [49] }\end{array}$ & Japan & $\begin{array}{l}\text { Mouse } \\
\text { C57BL/6, F }\end{array}$ & 20 & 25 & BLM & BMSC & $5.0 \times 10^{6}$ & iv & Allograft & $3 d$ & $10 \mathrm{~d}$ \\
\hline $\begin{array}{l}\text { Reddy et al. } \\
\text { (2016) [50] }\end{array}$ & India & $\begin{array}{l}\text { Mouse } \\
\text { Swiss-albino, } \\
\text { M }\end{array}$ & 10 & 10 & BLM & ADMSC & $4.0 \times 10^{7}$ & iv & Xenograft & $3 \mathrm{~d}, 6 \mathrm{~d}, 9 \mathrm{~d}$ & $21 d$ \\
\hline $\begin{array}{l}\text { Rojas et al. } \\
\text { (2005) [51] }\end{array}$ & USA & $\begin{array}{l}\text { Mouse } \\
\text { C57BL/6, NR }\end{array}$ & 5 & 6 & BLM & BMSC & $5.0 \times 10^{6}$ & iv & Allograft & $6 \mathrm{~h}$ & $14 \mathrm{~d}$ \\
\hline $\begin{array}{l}\text { Wang et al. } \\
\text { (2012) [40] }\end{array}$ & China & $\begin{array}{l}\text { Mouse } \\
\text { BALB/C, M }\end{array}$ & 6 & 6 & BLM & EMSC & $2.0 \times 10^{5}$ & iv & Xenograft & $1 \mathrm{~d}$ & $14 \mathrm{~d}$ \\
\hline $\begin{array}{l}\text { Lee et al. } \\
\text { (2014) [31] }\end{array}$ & Korea & $\begin{array}{l}\text { Mouse } \\
\text { C57BL/6, M }\end{array}$ & 10 & 20 & BLM & ADMSC & $3.0 \times 10^{5}$ & ip & Xenograft & $60 d$ & $60 d$ \\
\hline $\begin{array}{l}\text { Chen et al. } \\
\text { (2018) [52] }\end{array}$ & China & Rat, SD, M & 5 & 5 & Silica & ADMSC & $5.0 \times 10^{5}$ & iv & Allograft & $1 \mathrm{~d}$ & $28 d$ \\
\hline $\begin{array}{l}\text { Lee et al. } \\
\text { (2010) [53] }\end{array}$ & Korea & Rat, SD, F & 10 & 10 & BLM & BMSC & $1.0 \times 10^{7}$ & iv & Allograft & $4 d$ & $28 d$ \\
\hline $\begin{array}{l}\text { Periera-simon } \\
\text { et al. (2020) [21] }\end{array}$ & USA & $\begin{array}{l}\text { Mouse } \\
\text { C57BL/6, NR }\end{array}$ & 15 & 15 & BLM & ADMSC & $5.0 \times 10^{5}$ & iv & Xenograft & $1 d$ & $21 d$ \\
\hline $\begin{array}{l}\text { Aguilar et al. } \\
\text { (2009) [22] }\end{array}$ & UK & $\begin{array}{l}\text { Mouse } \\
\text { C57BL/6, M }\end{array}$ & 6 & 6 & BLM & BMSC & $\begin{array}{l}5.0 \times 10^{6} \\
(1 \mathrm{~d}, 3 \mathrm{~d})\end{array}$ & iv & Allograft & $8 \mathrm{~h}$ & $14 \mathrm{~d}$ \\
\hline $\begin{array}{l}\text { Chen et al. } \\
(2020) \text { [54] }\end{array}$ & China & $\begin{array}{l}\text { Mouse } \\
\text { C57BL/6, M }\end{array}$ & 5 & 5 & BLM & MenSC & $5.0 \times 10^{5}$ & iv & Xenograft & $2 d, 7 d$ & $21 \mathrm{~d}$ \\
\hline $\begin{array}{l}\text { Lan et al. } \\
\text { (2015) [38] }\end{array}$ & China & $\begin{array}{l}\text { Mouse } \\
\text { C57BL/6, F }\end{array}$ & 6 & 6 & BLM & BMSC & $5.0 \times 10^{5}$ & it & Allograft & $3 d$ & $21 \mathrm{~d}$ \\
\hline Yuben et al. & Australia & Mouse, & 8 & 8 & BLM & UCMSC & $1.0 \times 10^{6}$ & iv & Xenograft & $1 \mathrm{~d}$ & $28 d$ \\
\hline
\end{tabular}


Table 1 General characteristics of preclinical studies investigating the efficacy of MSC therapy in models of PF (Continued)

\begin{tabular}{|c|c|c|c|c|c|c|c|c|c|c|c|}
\hline Author (year) & Country & $\begin{array}{l}\text { Species, } \\
\text { strain, } \\
\text { gender }\end{array}$ & $\begin{array}{l}\text { No. of treated } \\
\text { animals }\end{array}$ & $\begin{array}{l}\text { No. of } \\
\text { controls }\end{array}$ & $\begin{array}{l}\mathrm{PF} \\
\text { model }\end{array}$ & $\begin{array}{l}\text { MSC } \\
\text { source }\end{array}$ & $\begin{array}{l}\text { MSC } \\
\text { dose }\end{array}$ & $\begin{array}{l}\text { MSC } \\
\text { route }\end{array}$ & $\begin{array}{l}\text { Transplant } \\
\text { type }\end{array}$ & $\begin{array}{l}\text { Time of MSC } \\
\text { therapy after } \\
\text { PF }\end{array}$ & $\begin{array}{l}\text { Follow- } \\
\text { up } \\
\text { (days) }\end{array}$ \\
\hline (2009) [55] & & $S C I D, N R$ & & & & & & & & & \\
\hline $\begin{array}{l}\text { Moodley et al. A } \\
\text { (2013) [17] }\end{array}$ & Australia & $\begin{array}{l}\text { Mouse } \\
\text { C57BL/6, F }\end{array}$ & 8 & 8 & BLM & BMSC & $1.0 \times 10^{6}$ & iv & Xenograft & $3 d$ & $21 \mathrm{~d}$ \\
\hline $\begin{array}{l}\text { Moodley et al. B } \\
\text { (2013) }\end{array}$ & Australia & $\begin{array}{l}\text { Mouse } \\
\text { C57BL/6, F }\end{array}$ & 8 & 8 & BLM & AMSC & $1.0 \times 10^{6}$ & iv & Xenograft & $3 d$ & $21 d$ \\
\hline
\end{tabular}

PF pulmonary fibrosis, SD Sprague Dawley, $M$ male, $F$ female, NR not reported, MSC mesenchymal stem cell, BLM bleomycin, $P Q$ paraquat, $B M S C$ bone marrow mesenchymal stem cells, UCMSC umbilical cord mesenchymal stem cells, ADMSC adipose-derived mesenchymal stem cells, EMSC human embryonic mesenchymal stem cells, AMSC amniotic mesenchymal stem cells, MenSC human menstrual blood-derived mesenchymal stem cells, iv intravenous, ip intraperitoneally, it intratracheally. Follow-up (days) suggests the observation time of outcomes after mesenchymal stem cell administration

in the randomization sequence was judged to be "unclear." In addition, because of the special properties of mesenchymal stem cell administration, it is difficult for researchers to achieve a blinding procedure when acquiring stem cells, although this does not influence the experimental results. The majority of studies were scored as having a low risk of reporting and attrition bias. The risk of bias was unclear for all articles across the domains of allocation concealment, random animal housing, and random outcome assessment. Moreover, no additional sources of bias were identified.

\section{Efficacy of MSC therapy on PF Survival rate}

In this meta-analysis, a total of 12 animal studies reported survival rate. A fixed effects model was used to assess this research, as the heterogeneity was low $\left(I^{2}=\right.$ $0 \%$ and $P=0.84$ ). Animals treated with MSCs had a significantly increasing survival rate compared to control (OR 3.10, 95\% CI 2.06 to 4.67, $P<0.001$ ) (Fig. 3).

\section{Pulmonary fibrosis scores}

The results of pulmonary fibrosis scores in this metaanalysis are shown in Fig. 4. The pooled weighted mean difference (WMD) for pulmonary fibrosis scores was -2.05 (95\% CI -2.58 to -1.51 ), and the $P$ values were less than 0.001 , which demonstrated that MSC therapy was associated with an obvious reduction in pulmonary fibrosis scores compared with that in the control group. The significant heterogeneity was detected in this study $\left(I^{2}=90 \%\right.$ and $P<0.01)$; thus, a random effects model was used.

\section{Subgroup analysis and meta-regression analysis}

We analyzed the source of heterogeneity by evaluating pulmonary fibrosis scores in a subgroup analysis (Table 2, Additional file 3: Fig. S1-S7). We focused on MSC type, dose, time, injection route, type of graft, PF model, and geographic location, which were reported in tables, respectively. The composite WMDs (95\% CI) for the PF model (silica-induced) and MSC type (BMSC) were
$-1.55(-2.52$ to -0.57$), I^{2}=0 \%$, and $-1.22(-1.68$ to $-0.76), I^{2}=60 \%(P<0.01)$, respectively. With regard to MSC dose, the composite WMDs (95\% CI) for highdose BMSC and high-dose ADMSC were -1.00 (-1.42 to -0.58$), I^{2}=14 \%$, and $-2.46(-3.28$ to -2.00$), I^{2}=0 \%$, respectively $(P<0.01)$ (Additional file 3 : Fig. S8-S9).

To further identify the potential heterogeneity across studies, we estimated the effect of all variables on the study results by using meta-regression. For pulmonary fibrosis scores, MSC type remained the only significant factor $(P=0.008)$, indicating that MSC type may be the source of heterogeneity in this meta-analysis (Additional file 4: Table S3).

\section{Sensitivity analyses}

Sensitivity analyses were performed using "one-study-removed" analyses. We used sensitivity analyses to evaluate whether the pooled effect size still fell within the total pooled effect size of the $95 \% \mathrm{CI}$, indicating that the outcomes of the meta-analysis were stable (Additional file 5: Fig. S10).

\section{Publication bias}

Funnel plots and Egger's regression tests were used to assess publication bias in survival rate and pulmonary fibrosis scores individually (Additional file 6: Fig. S11). The Funnel plots and Egger's regression tests $(P=0.015)$ showed publication bias in survival rate and no significant publication bias in pulmonary fibrosis scores $(P=$ 0.702).

\section{Discussion}

This meta-analysis evaluated the efficacy of MSC therapy in preclinical models of pulmonary fibrosis. In general, the results of our meta-analysis indicate an improvement in lung damage with MSC treatment, which is consistent with the previous meta-analysis [30]. While this previous meta-analysis only included the animal model of PF induced by bleomycin, we updated another three PF models, including silica, paraquat, and radiation, and analyzed another important parameter 


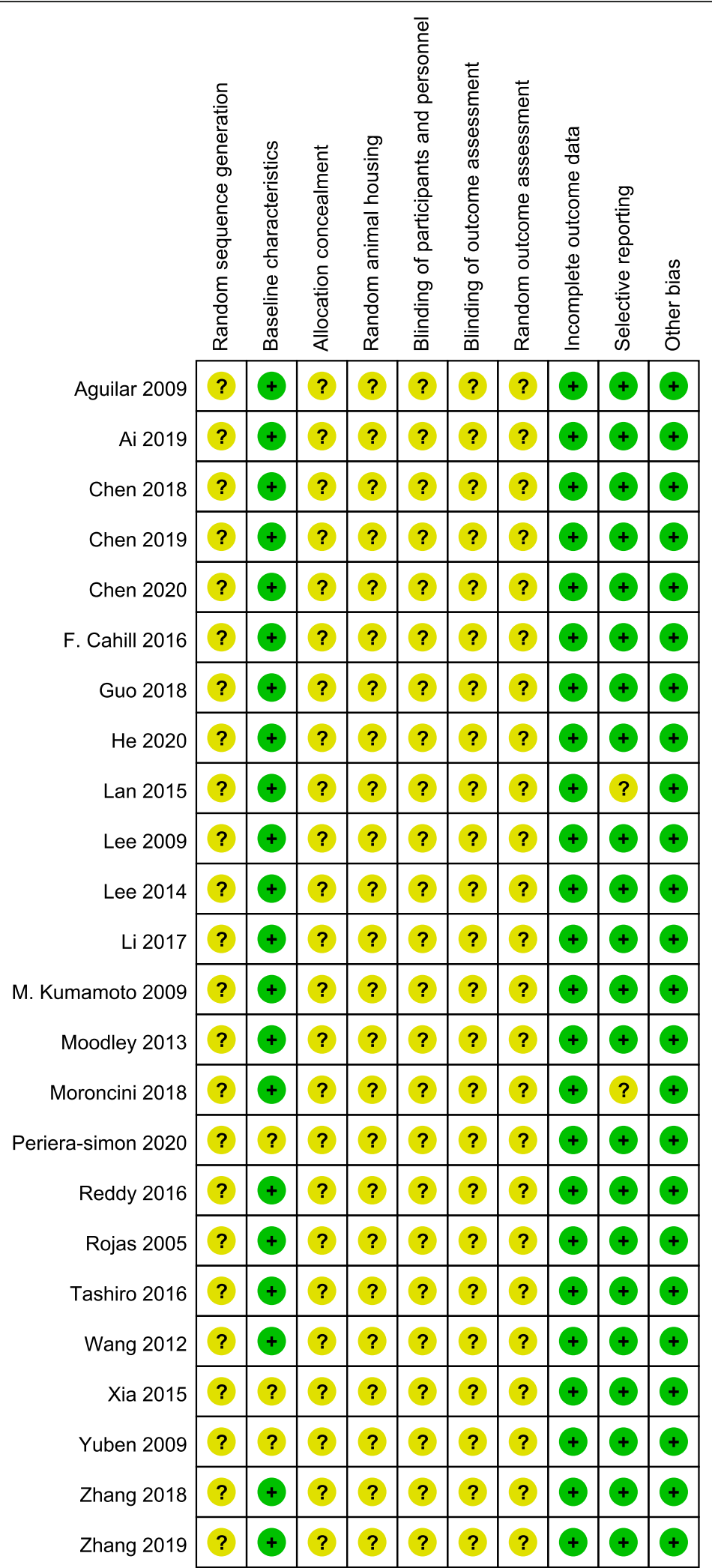

Fig. 2 Risk of bias assessment using the SYRCLE tool 


\begin{tabular}{|c|c|c|c|c|c|c|c|c|c|c|}
\hline Study or Subgroup & $\begin{array}{l}\text { MSCs } \\
\text { Events } \\
\end{array}$ & Total & $\begin{array}{l}\text { Contrc } \\
\text { Events }\end{array}$ & $\begin{array}{l}\text { ol } \\
\text { Total }\end{array}$ & Weight & $\begin{array}{c}\text { Odds Ratio } \\
\text { M-H. Fixed. } 95 \% \mathrm{Cl}\end{array}$ & & $\begin{array}{r}\text { Odds } \\
\text { M-H. Fixe }\end{array}$ & $\begin{array}{l}\text { Ratio } \\
\text { ed. } 95 \% \mathrm{Cl}\end{array}$ & \\
\hline Chen 2019 & 7 & 10 & 5 & 10 & $5.6 \%$ & $2.33[0.37,14.61]$ & & & & \\
\hline Guo 2018 & 20 & 20 & 10 & 20 & $0.9 \%$ & $41.00[2.18,770.08]$ & & & & \\
\hline He 2020 & 15 & 22 & 7 & 20 & $8.8 \%$ & $3.98[1.10,14.37]$ & & & & \\
\hline Lee 2010 & 28 & 30 & 26 & 30 & $6.5 \%$ & $2.15[0.36,12.76]$ & & & & \\
\hline M. Kumamoto 2009 & 17 & 23 & 13 & 25 & $12.2 \%$ & $2.62[0.77,8.83]$ & & & & \\
\hline Periera-simon 2020 & 10 & 15 & 6 & 15 & $7.5 \%$ & $3.00[0.68,13.31]$ & & & & \\
\hline Reddy 2016 & 7 & 10 & 3 & 10 & $3.4 \%$ & $5.44[0.80,36.87]$ & & & & \\
\hline Rojas 2005 & 5 & 5 & 2 & 6 & $0.7 \%$ & $19.80[0.74,527.26]$ & & & & \\
\hline Wang 2012 & 18 & 30 & 12 & 30 & $18.1 \%$ & $2.25[0.80,6.32]$ & & & & \\
\hline Xia (A) 2015 & 21 & 25 & 16 & 25 & $9.6 \%$ & $2.95[0.77,11.34]$ & & & & \\
\hline Xia (B) 2015 & 20 & 25 & 16 & 25 & $12.0 \%$ & $2.25[0.63,8.06]$ & & & & \\
\hline Xia (C) 2015 & 19 & 25 & 16 & 25 & $14.5 \%$ & $1.78[0.52,6.09]$ & & & & \\
\hline Total $(95 \% \mathrm{Cl})$ & & 240 & & 241 & $100.0 \%$ & $3.10[2.06,4.67]$ & & & & \\
\hline Total events & 187 & & 132 & & & & & & & \\
\hline \multicolumn{7}{|c|}{$\begin{array}{l}\text { Heterogeneity: } \mathrm{Chi}^{2}=6.41, \mathrm{df}=11(P=0.84) ; I^{2}=0 \% \\
\text { Test for overall effect: } Z=5.41(P<0.00001)\end{array}$} & 0.01 & $\begin{array}{cc}0.1 & 1 \\
\text { Favours [control] }\end{array}$ & $\begin{array}{l}10 \\
\text { Favours [MSCs] }\end{array}$ & 100 \\
\hline
\end{tabular}

(survival rate), for providing more possibilities for MSC therapy in preclinical studies of PF.

In our research, the majority of MSCs were derived from fresh tissue of healthy rodents or humans. The culture medium was changed every 2-3 days until cell confluency reached $>80 \%$. Generations $2-5$ of the MSCs were harvested for the identification and cell administration studies [10, 23, 31]. In the field of regenerative medicine, animal studies are relevant to clinical application and used to evaluate the safety and efficacy of MSC therapy. As far as we know, several clinical trials have been conducted to explore the potential benefits of MSC transplantation for patients with IPF [32-36]. A phase $1 \mathrm{~b}$ clinical trial reported that the intravenous route of up to $2 \times 10^{6}$ placental MSCs per kilogram is safe in patients with moderately severe IPF. They found that this intervention was not associated with significant adverse reactions and that lung function, 6-min walk distance (6MWD), and computed tomography (CT) fibrosis score were unchanged over 6 months compared with baseline [35]. Another clinical trial indicated a total dose of $1.6 \times$ $10^{9}$ MSCs is well tolerated by IPF patients with a rapid

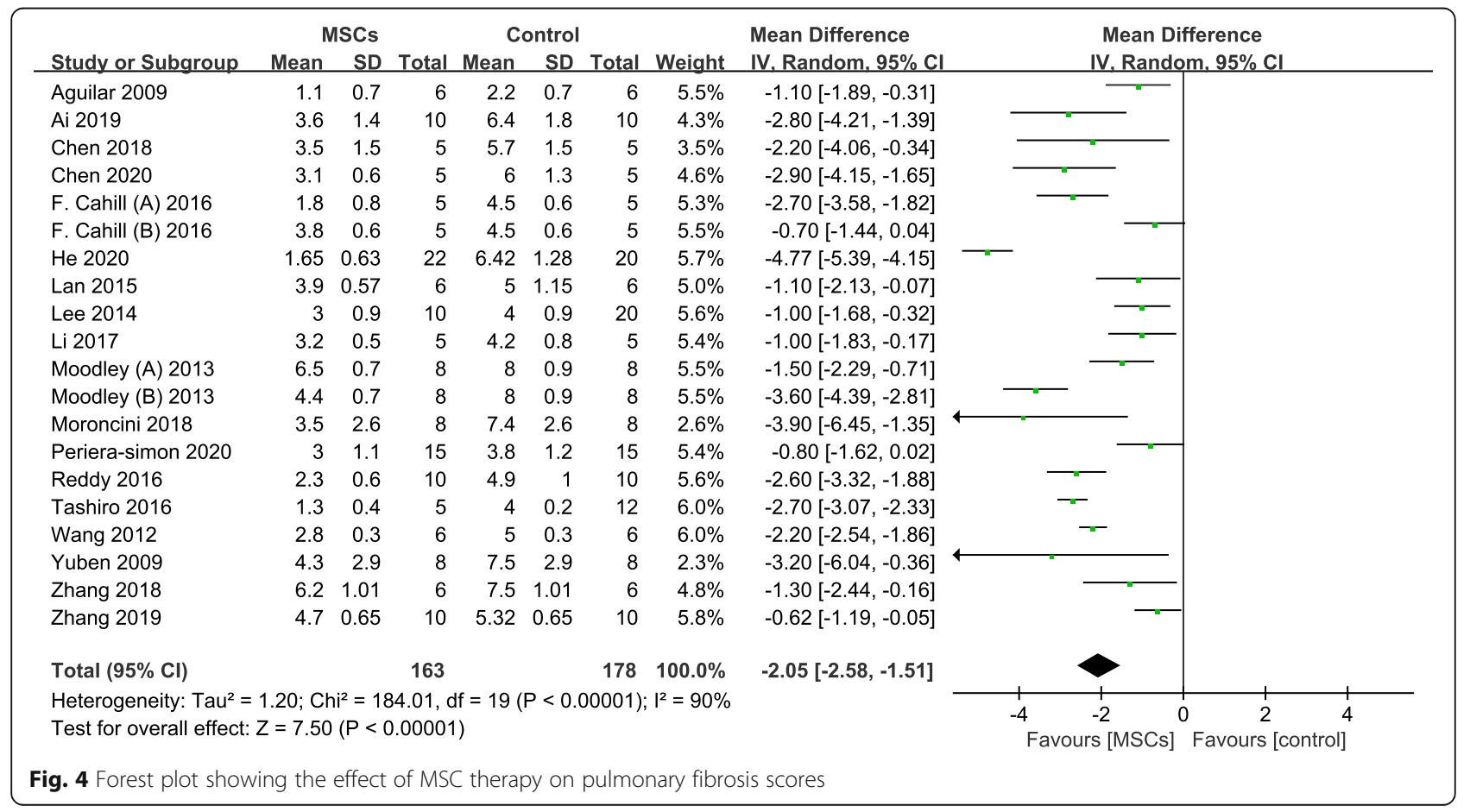


Table 2 The study of correlation grouping and heterogeneity between pulmonary fibrosis scores and variables

\begin{tabular}{|c|c|c|c|}
\hline Subgroup & Weighted mean $(95 \% \mathrm{Cl})$ & $I^{2}$ & $P$ \\
\hline \multicolumn{4}{|l|}{ PF model } \\
\hline Bleomycin-induced PF model & $-2.03(-2.51,-1.56)$ & $82 \%$ & $<0.01$ \\
\hline Silica-induced PF model & $-1.55(-2.52,-0.57)$ & $0 \%$ & $<0.01$ \\
\hline Paraquat-induced PF model & $-2.69(-6.76,1.37)$ & $99 \%$ & $<0.01$ \\
\hline Radiation-induced PF model & $-1.00(-1.83,-0.17)$ & NA & 0.02 \\
\hline \multicolumn{4}{|l|}{ MSC route } \\
\hline Intravenous injection & $-2.77(-2.83,-1.71)$ & $88 \%$ & $<0.01$ \\
\hline Non-intravenous injection & $-0.83(-1.23,-0.42)$ & $0 \%$ & 0.6 \\
\hline \multicolumn{4}{|l|}{ MSC type } \\
\hline BMSC & $-1.22(-1.68,-0.76)$ & $60 \%$ & $<0.01$ \\
\hline ADMSC & $-1.98(-2.79,-1.17)$ & $84 \%$ & $<0.01$ \\
\hline Others & $-3.41(-4.61,-2.22)$ & $91 \%$ & $<0.01$ \\
\hline \multicolumn{4}{|l|}{ MSC dose } \\
\hline$<1.0 \times 10^{6} \mathrm{MSCs}$ & $-1.79(-2.33,-1.25)$ & $83 \%$ & $<0.01$ \\
\hline$\geq 1.0 \times 10^{6} \mathrm{MSCS}$ & $-2.34(-3.45,-1.23)$ & $93 \%$ & $<0.01$ \\
\hline \multicolumn{4}{|l|}{ Time of MSC therapy } \\
\hline$\leq 1 \mathrm{~d}$ & $-2.21(-2.96,-1.47)$ & $92 \%$ & $<0.01$ \\
\hline$>1 d$ & $-1.83(-2.59,-1.07)$ & $84 \%$ & $<0.01$ \\
\hline \multicolumn{4}{|l|}{ Type of graft } \\
\hline Allograft & $-1.58(-2.25,-0.91)$ & $86 \%$ & $<0.01$ \\
\hline Xenograft & $-2.55(-3.40,-1.70)$ & $91 \%$ & $<0.01$ \\
\hline \multicolumn{4}{|l|}{ Geographic location } \\
\hline Asia & $-2.03(-2.84,-1.23)$ & $92 \%$ & $<0.01$ \\
\hline Europe & $-1.79(-2.95,-0.64)$ & $81 \%$ & $<0.01$ \\
\hline America & $-1.79(-3.65,-0.07)$ & $94 \%$ & $<0.01$ \\
\hline Oceania & $-2.68(-4.38,-0.98)$ & $85 \%$ & $<0.01$ \\
\hline
\end{tabular}

lung function decline, which can improve 6MWD in 13 weeks and lung function in 39 weeks [36]. Even though MSC therapy is a generally safe and promising candidate to slow the disease progression in these clinical trials, the best way of MSC therapy remains unclear.

In our meta-analysis, MSC treatment obviously improved the survival rate and fibrosis scores of PF animal models, indicating the potentials of MSC transplantation in preclinical studies of PF. We investigated the efficacy of different MSC sources and found that the most common type of employed stem cells was BMSC or ADMSC (54/21\%). However, our study reported that other types of MSC (AMSC, UCMSC, EMSC, and MenSC) showed better treatment results in regard to pulmonary fibrosis scores. Due to the lack of related reports, more rigorous studies treated with MSCs are required to verify these findings. In addition, recent studies involving overexpressing specific genes [37] in engrafted stem cells or preconditioned MSCs have shown improvement on survival rate and lung fibrosis following MSC administration [38-40]. In fact, confirmatory studies of two models could improve the validity; however, we did not collect and identify any studies regarding stem cell therapy in gene modification.

We attempt to explore the heterogeneity from different design projects, including different stem cell types, injection routes, time intervals, and dosages of MSCs. According to subgroup analysis and meta-regression, we found that the possible contributor of heterogeneity is the PF model, MSC type, and MSC dose. There are many interventions that can induce pulmonary fibrosis, including bleomycin, silica, paraquat, radiation, and so on, which have their advantages and disadvantages. The pathological features of the PF model diverge in many aspects may be the reason for the different therapeutic effects. Migrated MSCs play an important function in injury repair by differentiating into different tissue, anti-apoptotic, immunomodulation, and anti-inflammatory effects [18]. At the same time, the adverse environment around the damaged lung may also affect the efficacy of implanted MSCs [41]. 
The success of MSC therapy is partly reliant on a sufficient number of cells reaching the target organ and appropriate timing of stem cell injection. In murine studies, the effective dose for stem cell treatment is normally $1.0 \times 10^{6}$ per $30 \mathrm{~g}$ mouse. And the early transplantation of MSCs within 1 day after lung damage is the most valuable method for repairing fibrotic sites [42]. Subgroup analyses were performed according to the dosage of MSCs $\left(<1.0 \times 10^{6}\right.$ MSCs or $\geq 1.0 \times 10^{6}$ MSCs) and time of MSC therapy ( $\leq 1$ day or $>1$ day) and indicated that early stem cell therapy and high dose of MSCs in the experimental group appear to be more effective than in the control group. However, the majority of reports treated animals with stem cells prior to injury or evidence of $\mathrm{PF}$, suggesting that MSC therapy does not show a significant effect on the subsequent collagen deposition and fibrosis prevention when administrating few days after the lung damage. The intravenous injection had a greater effect size than other routes, demonstrating that this method had better therapeutic value, although the effect sizes remained large for other routes also. Furthermore, xenograft therapy in PF animals was more effective than allograft therapy, implying that graft type is a crucial factor in clinical application for PF therapy. However, the sample size of this subgroup analysis was small, and there may be false-positive or false-negative conclusions.

The SYRCLE Risk of Bias tool was used to assess the translational potentials of MSC therapy [26]. In this meta-analysis, none of 24 articles was identified as having a low risk of bias according to the reporting contents in this tool. Even though most of the studies tried to avoid all kinds of bias, few researchers attempt to show their protocols. Consequently, we could not estimate the effect size for follow-up studies based on this tool. The low quality of methodology was mainly caused by inappropriate sequence generation, lack of double-blinding and allocation concealment, selective reporting, and incomplete outcome data. This meta-analysis highlights the common problems and recommends an urgent need for higher methodological quality when publishing. To reduce the risk of bias and take the poor reporting of outcome measures into consideration, we suggest that future translational studies related to MSC-based PF treatment should follow the SYRCLE Risk of Bias tool and report both detailed methodology and measures' performance.

There are several strengths in our meta-analysis. Firstly, this study for the first time evaluated the survival rate on the PF model in preclinical research. Even though a previous meta-analysis evaluated the benefits of MSCs in a BLM-induced animal model, the metaanalysis reported here incudes different PF models and recently published high-quality studies. Secondly, we performed a systematic literature search, comprehensive data collection, and subgroup analysis by MSC type, injection route, and timing, which can improve the accuracy of our findings. Thirdly, the main results about survival rate and pulmonary fibrosis scores could provide vital insight into the future study.

However, our study also has some limitations. Firstly, the funnel plots and Egger's regression tests detected that publication bias exists in this meta-analysis. As expected, studies reporting positive results are easier to publish, especially in animal studies. Secondly, the included studies were limited to those that had been published. The outcomes will be altered when undocumented data are published. Thirdly, current data mostly focus on the effect of MSC administration prior to injury or evidence of $\mathrm{PF}$, while results of late administration are limited. Whether MSC therapy can significantly alleviate pulmonary fibrosis and produce longterm therapeutic effects on regeneration is worth further exploration. Fourthly, the diagnostic approach to PF is reliant on high-resolution chest computed tomography (HRCT), pulmonary function tests, and histologic findings [1]. Among them, HRCT and pulmonary function tests are more conductive to clinical application. However, most of the studies in our meta-analysis did not use HRCT and lung function for diagnosis. Therefore, it is suggested that future preclinical studies should concentrate on MSC transplantation at a more advanced stage and non-invasive diagnosis.

\section{Conclusion}

In conclusion, this meta-analysis evaluated the efficacy of mesenchymal stem cell therapy on survival rate and pulmonary fibrosis scores in animal models, which provides an important basis for future translational clinical studies. Due to the low methodological quality, large sample, prospective, double-blind, randomized controlled trials are required to prove the safety and efficacy of MSC therapy for IPF.

\section{Abbreviations \\ MSC: Mesenchymal stem cell; IPF: Idiopathic pulmonary fibrosis; SYRC LE: Systematic Review Centre for Laboratory Animal Experimentation; PQ: Paraquat; WMD: Weighted mean difference}

\section{Supplementary Information}

The online version contains supplementary material available at https://doi. org/10.1186/s13287-021-02496-2

Additional file 1: Table S1. PRISMA 2009 Checklist.

Additional file 2: Table S2. The detailed search strategy.

Additional file 3: Figure S1. Forest plot summarizing the relationship between PF models and pulmonary fibrosis scores in preclinical models of PF. Figure S2. Forest plot summarizing the relationship between MSC type and pulmonary fibrosis scores in preclinical models of PF. Figure S3. Forest plot summarizing the relationship between MSC dose and 
pulmonary fibrosis scores in preclinical models of PF. Figure S4. Forest plot summarizing the relationship between MSC route and pulmonary fibrosis scores in preclinical models of PF. Figure S5. Forest plot summarizing the relationship between transplant type and pulmonary fibrosis scores in preclinical models of PF. Figure S6. Forest plot summarizing the relationship between timing of MSC therapy after PF and pulmonary fibrosis scores in preclinical models of PF. Figure S7. Forest plot summarizing the relationship between geographic location and pulmonary fibrosis scores in preclinical models of PF. Figure $\mathbf{S 8 .}$ Forest plot summarizing the relationship between BMSC dose and pulmonary fibrosis scores in preclinical models of PF. Figure S9. Forest plot summarizing the relationship between ADMSC dose and pulmonary fibrosis scores in preclinical models of PF.

Additional file 4: Table S3. Meta-regression showing the possible source of heterogeneity of meta-analysis.

Additional file 5: Fig. S10. Sensitivity analyses: a) survival rate, b) pulmonary fibrosis scores.

Additional file 6: Fig. S11. Funnel plots for (a) survival rate, (b) pulmonary fibrosis scores.

\section{Acknowledgements}

Not applicable.

\section{Authors' contributions}

All the authors contributed extensively to the work presented in this article. DYL, RFL, and DDP conceived the study. DYL and RFL performed the literature search and analyzed the data. DXS and DDP contributed to key data interpretation. DYL and RFL contributed to the study protocol and wrote the article. DXS and DDP resolved any differences through discussions. YHZ revised the article. The corresponding author had full access to the data and has final responsibility for the article submitted for publication. All authors read and approved the final manuscript.

\section{Funding}

This work was supported by the open subject of the first people's hospital of Yunnan Province (2020LCZXKF-HX08).

\section{Availability of data and materials}

All supporting data are included in the article and its additional files.

\section{Declarations}

\section{Ethics approval and consent to participate}

Not applicable.

\section{Consent for publication}

Not applicable.

\section{Competing interests}

The authors declare that they have no competing interests.

\section{Author details}

${ }^{1}$ Faculty of Life Science and Technology, Kunming University of Science and Technology, Kunming 650500, People's Republic of China. ${ }^{2}$ The Affiliated Hospital of Kunming University of Science and Technology, Kunming 650500, People's Republic of China. ${ }^{3}$ Department of Pulmonary and Critical Care Medicine, The First People's Hospital of Yunnan Province, Kunming 650022. People's Republic of China.

\section{Received: 4 June 2021 Accepted: 5 July 2021}

Published online: 18 August 2021

\section{References}

1. Raghu G, Remy-Jardin M, Myers JL, Richeldi L, Ryerson CJ, Lederer DJ, et al. Diagnosis of idiopathic pulmonary fibrosis. An official ATS/ERS/JRS/ALAT clinical practice guideline. Am J Respir Crit Care Med. 2018;198(5):e44-68. https://doi.org/10.1164/rccm.201807-1255ST.

2. Olson AL, Gifford AH, Inase N, Fernandez Perez ER, Suda T. The epidemiology of idiopathic pulmonary fibrosis and interstitial lung diseases at risk of a progressive-fibrosing phenotype. European respiratory review: an official journal of the European Respiratory Society. 2018;27(150).

3. Herrera J, Henke CA, Bitterman PB. Extracellular matrix as a driver of progressive fibrosis. J Clin Investig. 2018;128(1):45-53. https://doi.org/10.11 72/JC193557.

4. Lynch DA, Sverzellati N, Travis WD, Brown KK, Colby TV, Galvin JR, et al. Diagnostic criteria for idiopathic pulmonary fibrosis: a Fleischner Society White Paper. Lancet Respir Med. 2018;6(2):138-53. https://doi.org/10.1016/ S2213-2600(17)30433-2.

5. Raghu G, Rochwerg B, Zhang Y, Garcia CA, Azuma A, Behr J, et al. An official ATS/ERS/JRS/ALAT clinical practice guideline: treatment of idiopathic pulmonary fibrosis. An update of the 2011 clinical practice guideline. Am J Respir Crit Care Med. 2015;192(2):e3-19. https://doi.org/10.1164/rccm.201 506-1063ST.

6. Duckworth A, Gibbons MA, Allen RJ, Almond H, Beaumont RN, Wood AR, et al. Telomere length and risk of idiopathic pulmonary fibrosis and chronic obstructive pulmonary disease: a Mendelian randomisation study. Lancet Respir Med. 2021;9(3):285-94. https://doi.org/10.1016/\$2213-2600(20)303647.

7. Wells AU, Flaherty KR, Brown KK, Inoue Y, Devaraj A, Richeldi L, et al. Nintedanib in patients with progressive fibrosing interstitial lung diseasessubgroup analyses by interstitial lung disease diagnosis in the INBUILD trial: a randomised, double-blind, placebo-controlled, parallel-group trial. Lancet Respir Med. 2020;8(5):453-60. https://doi.org/10.1016/\$2213-2600(20)300369.

8. Crestani B, Huggins JT, Kaye M, Costabel U, Glaspole I, Ogura T, et al. Longterm safety and tolerability of nintedanib in patients with idiopathic pulmonary fibrosis: results from the open-label extension study. INPULSISON The Lancet Respiratory medicine. 2019;7(1):60-8. https://doi.org/10.101 6/S2213-2600(18)30339-4.

9. Noble PW, Albera C, Bradford WZ, Costabel U, Glassberg MK, Kardatzke D, et al. Pirfenidone in patients with idiopathic pulmonary fibrosis (CAPACITY): two randomised trials. Lancet. 2011;377(9779):1760-9. https://doi.org/10.101 6/S0140-6736(11)60405-4.

10. Chen JJ, Si L, Zhou LL, Deng YJ. Role of bone marrow mesenchymal stem cells in the development of PQ-induced pulmonary fibrosis. Mol Med Rep. 2019;19(4):3283-90. https://doi.org/10.3892/mmr.2019.9976.

11. Abdel Halim AS, Ahmed HH, Aglan HA, Abdel Hamid FF, Mohamed MR. Role of bone marrow-derived mesenchymal stem cells in alleviating pulmonary epithelium damage and extracellular matrix remodeling in a rat model of lung fibrosis induced by amiodarone. Biotechnic \& histochemistry: official publication of the Biological Stain Commission. 2020:1-13.

12. Moghadasali R. Autologous bone marrow mesenchymal stem cells prevent progression of chronic kidney disease but do not reduce of interstitial fibrosis in a rhesus macaque mulatta monkey model. Int J Urol. 2014;21: A172.

13. Schmuck EG, Hacker TA, Schreier DA, Chesler NC, Wang ZJ. Beneficial effects of mesenchymal stem cell delivery via a novel cardiac bioscaffold on right ventricles of pulmonary arterial hypertensive rats. Am J Phys Heart Circ Phys. 2019;316(5):H1005-H13.

14. Baligar P, Kochat V, Arindkar SK, Equbal Z, Mukherjee S, Patel S, et al. Bone marrow stem cell therapy partially ameliorates pathological consequences in livers of mice expressing mutant human a1-antitrypsin. Hepatology. 2017; 65(4):1319-35. https://doi.org/10.1002/hep.29027.

15. Kawamura M, Miyagawa S, Saito A, Fukushima S, Shudo Y, Ishikawa T, et al. Cell sheet transplantation in porcine ischemic cardiomyopathy model; comparison of skeletal myoblast and bone marrow-derived mesenchymal stem cell. Eur Heart J. 2012;33:431-2.

16. Yu SH, Liu LJ, Lv B, Che CL, Fan DP, Wang LF, et al. Inhibition of bleomycininduced pulmonary fibrosis by bone marrow-derived mesenchymal stem cells might be mediated by decreasing MMP9, TIMP-1, INF- $\gamma$ and TGF- $\beta$. Cell Biochem Funct. 2015;33(6):356-66. https://doi.org/10.1002/cbf.3118.

17. Moodley Y, Vaghjiani V, Chan J, Baltic S, Ryan M, Tchongue J, et al. Antiinflammatory effects of adult stem cells in sustained lung injury: a comparative study. PLoS One. 2013;8(8).

18. Cieslik KA, Trial J, Entman ML. Aicar treatment reduces interstitial fibrosis in aging mice: suppression of the inflammatory fibroblast. J Mol Cell Cardiol. 2017;111:81-5. https://doi.org/10.1016/j.yjmcc.2017.08.003.

19. He F, Wang Y, Li Y, Yu L. Human amniotic mesenchymal stem cells alleviate paraquat-induced pulmonary fibrosis in rats by inhibiting the inflammatory response. Life Sci. 2020;243:117290. https://doi.org/10.1016/j.lfs.2020.117290. 
20. Zhang $L C, L i Q H$, Liu ZN, Wang Y, Zhao M. The protective effects of bone mesenchymal stem cells on paraquat-induced acute lung injury via the muc5b and ERK/MAPK signaling pathways. Am J Transl Res. 2019;11(6):3707-21.

21. Periera-Simon S, Xia XM, Catanuto P, Coronado R, Kurtzberg J, Bellio M, et al. Anti-fibrotic effects of different sources of MSC in bleomycin-induced lung fibrosis in C57BL6 male mice. Respirology (Carlton, Vic). 2021;26(2):161-70.

22. Aguilar S, Scotton CJ, McNulty K, Nye E, Stamp G, Laurent G, et al. Bone marrow stem cells expressing keratinocyte growth factor via an inducible lentivirus protects against bleomycin-induced pulmonary fibrosis. PLoS One. 2009;4(11):e8013. https://doi.org/10.1371/journal.pone.0008013.

23. Guo DB, Zhu XQ, Li QQ, Liu GMY, Ruan GP, Pang RQ, et al. Efficacy and mechanisms underlying the effects of allogeneic umbilical cord mesenchymal stem cell transplantation on acute radiation injury in tree shrews. Cytotechnology. 2018;70(5):1447-68. https:/doi.org/10.1007/s10616-018-0239-z.

24. Zhang E, Yang Y, Chen S, Peng C, Lavin MF, Yeo AJ, et al. Bone marrow mesenchymal stromal cells attenuate silica-induced pulmonary fibrosis potentially by attenuating $W n t / \beta$-catenin signaling in rats. Stem Cell Res Ther. 2018;9(1):311. https://doi.org/10.1186/s13287-018-1045-4.

25. Moher D, Liberati A, Tetzlaff J, Altman DG. Preferred reporting items for systematic reviews and meta-analyses: the PRISMA statement. BMJ (Clinical research ed). 2009:339:b2535.

26. Hooijmans CR, Rovers MM, de Vries RB, Leenaars M, Ritskes-Hoitinga M, Langendam MW. SYRCLE's risk of bias tool for animal studies. BMC Med Res Methodol. 2014;14(1):43. https://doi.org/10.1186/1471-2288-14-43.

27. Ashcroft T, Simpson JM, Timbrell V. Simple method of estimating severity of pulmonary fibrosis on a numerical scale. J Clin Pathol. 1988;41(4):467-70 https://doi.org/10.1136/jcp.41.4.467

28. Higgins JP, Thompson SG. Quantifying heterogeneity in a meta-analysis. Stat Med. 2002;21(11):1539-58. https://doi.org/10.1002/sim.1186

29. Hayashino Y, Noguchi Y, Fukui T. Systematic evaluation and comparison of statistical tests for publication bias. Journal of epidemiology. 2005;15(6):23543. https://doi.org/10.2188/jea.15.235.

30. Zhang E, Yang Y, Zhang J, Ding G, Chen S, Peng C, et al. Efficacy of bone marrow mesenchymal stem cell transplantation in animal models of pulmonary fibrosis after exposure to bleomycin: a meta-analysis. Experimental and therapeutic medicine. 2019;17(3):2247-55. https://doi. org/10.3892/etm.2019.7205.

31. Lee SH, Lee EJ, Lee SY, Kim JH, Shim JJ, Shin C, et al. The effect of adipose stem cell therapy on pulmonary fibrosis induced by repetitive intratrachea bleomycin in mice. Exp Lung Res. 2014;40(3):117-25. https://doi.org/10.31 09/01902148.2014.881930.

32. Chang Y, Park SH, Huh JW, Lim CM, Koh Y, Hong SB. Intratracheal administration of umbilical cord blood-derived mesenchymal stem cells in a patient with acute respiratory distress syndrome. J Korean Med Sci. 2014; 29(3):438-40. https://doi.org/10.3346/jkms.2014.29.3.438.

33. Ilić N, Atkinson K. Manufacturing and use of human placenta-derived mesenchymal stromal cells for phase I clinical trials: establishment and evaluation of a protocol. Vojnosanit Pregl. 2014;71(7):651-9. https://doi.org/1 0.2298/NSP130410050l.

34. Chambers DC, Enever D, llic N, Sparks L, Whitelaw K, Ayres J, et al. A phase $1 \mathrm{~b}$ study of placenta-derived mesenchymal stromal cells in patients with idiopathic pulmonary fibrosis. Respirology (Carlton, Vic). 2014;19(7):1013-8.

35. Tzouvelekis A, Ntolios P, Ekonomou A, Koliakos G, Froudarakis M, Bouros D. A prospective, non randomized, clinical trial to study the safety and efficacy of the endobronchial autologous infusion of adipose-derived mesenchymal stem cells (ADMSCS) in patients with idiopathic pulmonary fibrosis (IPF). Eur Respir J. 2011:38

36. Averyanov A, Koroleva I, Konoplyannikov M, Revkova V, Lesnyak V, Kalsin V, et al. First-in-human high-cumulative-dose stem cell therapy in idiopathic pulmonary fibrosis with rapid lung function decline. Stem Cells Transl Med. 2020;9(1):6-16. https://doi.org/10.1002/sctm.19-0037.

37. Sun J, Shen H, Shao L, Teng X, Chen Y, Liu X, et al. HIF-1a overexpression in mesenchymal stem cell-derived exosomes mediates cardioprotection in myocardial infarction by enhanced angiogenesis. Stem Cell Res Ther. 2020; 11(1):373. https://doi.org/10.1186/s13287-020-01881-7.

38. Lan YW, Choo KB, Chen CM, Hung TH, Chen YB, Hsieh CH, et al. Hypoxiapreconditioned mesenchymal stem cells attenuate bleomycin-induced pulmonary fibrosis. Stem Cell Res Ther. 2015;6(1):97. https://doi.org/10.1186/ s13287-015-0081-6.

39. Gazdhar A, Susuri N, Hostettler K, Gugger M, Knudsen L, Roth M, et al. HGF expressing stem cells in usual interstitial pneumonia originate from the bone marrow and are antifibrotic. PLoS One. 2013;8(6):e65453. https://doi. org/10.1371/journal.pone.0065453.

40. Wang Q, Zhu H, Zhou WG, Guo XC, Wu MJ, Xu ZY, et al. N-Acetylcysteinepretreated human embryonic mesenchymal stem cell administration protects against bleomycin-induced lung injury. Am J Med Sci. 2013;346(2): 113-22. https://doi.org/10.1097/MAJ.0b013e318266e8d8.

41. Potier E, Ferreira E, Meunier A, Sedel L, Logeart-Avramoglou D, Petite H. Prolonged hypoxia concomitant with serum deprivation induces massive human mesenchymal stem cell death. Tissue Eng. 2007;13(6):1325-31. https://doi.org/10.1089/ten.2006.0325.

42. Yan X, Liu Y, Han Q, Jia M, Liao L, Qi M, et al. Injured microenvironment directly guides the differentiation of engrafted Flk-1(+) mesenchymal stem cell in lung. Exp Hematol. 2007;35(9):1466-75. https://doi.org/10.1016/j. exphem.2007.05.012

43. Li B, Li C, Zhu M, Zhang Y, Du J, Xu Y, et al. Hypoxia-induced mesenchymal stromal cells exhibit an enhanced therapeutic effect on radiation-induced lung injury in mice due to an increased proliferation potential and enhanced antioxidant ability. Cellular physiology and biochemistry: international journal of experimental cellular physiology, biochemistry, and pharmacology. 2017;44(4):1295-310.

44. Xia CC, Chang PY, Zhang YY, Shi WY, Liu B, Ding $\sqcup$, et al. Therapeutic effects of bone marrow-derived mesenchymal stem cells on radiation-induced lung injury. Oncol Rep. 2016;35(2):731-8. https://doi.org/10.3892/or.2015.4433.

45. Cahill EF, Kennelly H, Carty F, Mahon BP, English K. Hepatocyte growth factor is required for mesenchymal stromal cell protection against bleomycin-induced pulmonary fibrosis. Stem Cells Transl Med. 2016;5(10): 1307-18. https://doi.org/10.5966/sctm.2015-0337.

46. Moroncini G, Paolini C, Orlando F, Capelli C, Grieco A, Tonnini C, et al. Mesenchymal stromal cells from human umbilical cord prevent the development of lung fibrosis in immunocompetent mice. PLoS One. 2018; 13(6):e0196048. https://doi.org/10.1371/journal.pone.0196048.

47. Tashiro J, Elliot SJ, Gerth DJ, Xia X, Pereira-Simon S, Choi R, et al. Therapeutic benefits of young, but not old, adipose-derived mesenchymal stem cells in a chronic mouse model of bleomycin-induced pulmonary fibrosis. Translational research: the journal of laboratory and clinical medicine. 2015; 166(6):554-67.

48. Ai L, Zhang J, Hai B, Cao Y, Pu Y. 3D-AMSCs enhance adipose-derived mesenchymal stem cell properties and increase treatment effect. Acta Medica Mediterranea. 2020;36(1):621-7.

49. Kumamoto M, Nishiwaki T, Matsuo N, Kimura H, Matsushima K. Minimally cultured bone marrow mesenchymal stem cells ameliorate fibrotic lung injury. Eur Respir J. 2009;34(3):740-8. https://doi.org/10.1183/09031936.0012 8508.

50. Reddy M, Fonseca L, Gowda S, Chougule B, Hari A, Totey S. Human adipose-derived mesenchymal stem cells attenuate early stage of bleomycin induced pulmonary fibrosis: comparison with pirfenidone. International journal of stem cells. 2016;9(2):192-206. https://doi.org/10.152 83/ijsc16041.

51. Rojas M, Xu J, Woods CR, Mora AL, Spears W, Roman J, et al. Bone marrowderived mesenchymal stem cells in repair of the injured lung. Am J Respir Cell Mol Biol. 2005;33(2):145-52. https://doi.org/10.1165/rcmb.2004-03300C.

52. Chen S, Cui G, Peng C, Lavin MF, Sun X, Zhang E, et al. Transplantation of adipose-derived mesenchymal stem cells attenuates pulmonary fibrosis of silicosis via anti-inflammatory and anti-apoptosis effects in rats. Stem Cell Res Ther. 2018;9(1):110. https://doi.org/10.1186/s13287-018-0846-9.

53. Lee $S H$, Jang AS, Kim YE, Cha JY, Kim TH, Jung $S$, et al. Modulation of cytokine and nitric oxide by mesenchymal stem cell transfer in lung injury/ fibrosis. Respir Res. 2010;11(1):16. https://doi.org/10.1186/1465-9921-11-16.

54. Chen $X$, Wu Y, Wang Y, Chen L, Zheng W, Zhou S, et al. Human menstrual blood-derived stem cells mitigate bleomycin-induced pulmonary fibrosis through anti-apoptosis and anti-inflammatory effects. Stem Cell Res Ther. 2020;11(1):477. https://doi.org/10.1186/s13287-020-01926-x.

55. Moodley Y, Atienza D, Manuelpillai U, Samuel CS, Tchongue J, llancheran S, et al. Human umbilical cord mesenchymal stem cells reduce fibrosis of bleomycin-induced lung injury. Am J Pathol. 2009;175(1):303-13. https://doi. org/10.2353/ajpath.2009.080629.

\section{Publisher's Note}

Springer Nature remains neutral with regard to jurisdictional claims in published maps and institutional affiliations. 